\title{
ACTIVE MOUNTAIN BUILDING AND THE DISTRIBUTION OF “CORE” MAXILLARIINAE SPECIES IN TROPICAL MEXICO AND CENTRAL AMERICA
}

\author{
STEPHEN H. KIRBY \\ U.S. Geological Survey, 345 Middlefield Road, Menlo Park, California 94025, U.S.A.
}

\begin{abstract}
AвstRact. The observation that southeastern Central America is a hotspot for orchid diversity has long been known and confirmed by recent systematic studies and checklists. An analysis of the geographic and elevation distribution demonstrates that the most widespread species of "core" Maxillariinae are all adapted to life near sea level, whereas the most narrowly endemic species are largely distributed in wet highland environments. Drier, hotter lowland gaps exist between these cordilleras and evidently restrict the dispersal of the species adapted to wetter, cooler conditions. Among the recent generic realignments of "core" Maxillariinae based on molecular phylogenetics, the Camaridium clade is easily the most prominent genus in Central America and is largely restricted to the highlands of Costa Rica and Panama, indicating that this region is the ancestral home of this genus and that its dispersal limits are drier, lowland cordilleran gaps. The mountains of Costa Rica and Panama are among the geologically youngest topographic features in the Neotropics, reflecting the complex and dynamic interactions of numerous tectonic plates. From consideration of the available geological evidence, I conclude that the rapid growth of the mountain ranges in Costa Rica and Panama during the late Cenozoic times created, in turn, very rapid ranges in ecological life zones and geographic isolation in that part of the isthmus. Thus, I suggest that these recent geologic events were the primary drivers for accelerated orchid evolution in southeastern Central America.
\end{abstract}

Resumen. Desde hace muchos años, observaciones indican que sur-este de América Central es un punto de alta diversidad de orquídeas. Éstas han sido confirmadas recientemente por estudios en la sistemática y listas anotadas este grupo. Un análisis de la distribución geográfica y altitudinal, demuestra que las especies más ampliamente distribuidas del "core" Maxillariinae se encuentran adaptadas para desarrollarse en tierras bajas cerca del nivel del mar, mientras que las especies endémicas y con distribuciones restringidas se encuentran en zonas altas y húmedas. Entre los recientes re-arreglos del "core" Maxillariinae, basado en filogenética molecular, aparece que el caldo Camaridium es el género más prominente en América Central, y está restringido a las tierras altas de Costa Rica y Panamá, indicando además que esta región es su lugar de origen y que sus límites para su dispersión son las tierras bajas y más secas. Las montañas de Costa Rica y Panamá se encuentran entre los accidentes geográficos más jóvenes del Neotrópico, y es el resultado de la compleja y dinámica interacción de numerosas placas tectónicas. Considerando la información geológica disponible, se concluye que el rápido crecimiento de las cadenas montañosas de Costa Rica y Panamá durante el Cenozoico Tardío, produjo rápidos cambios en las zonas ecológicas y también aislamiento geográfico en parte del istmo centroamericano. Así, se sugiere que estos eventos geológicos recientes fueron los factores primarios que aceleraron la evolución de las orquídeas en el sur-este de América Central.

Key words: Central America, geology, geography, Orchidaceae, Maxillariinae, distribution

\section{Charles Darwin geologist}

In this bicentenary year of Charles Darwin's birth, it is noteworthy to commemorate his seminal research relating earthquakes and mountain building to environmental change and the biogeography of South America. The purpose of this paper is to apply and extend some of Darwin's concepts and observations to provide geological context and explanation for the reasons why southeastern Central is such a hotspot 
for orchid evolution. However, before I discuss the interplay between mountain belts (and associated lowland gaps), geologic processes, and biological diversity, it is important to review briefly the life and contributions of Charles Darwin as the emerging science of geology developed in the 19th century.

It is sometimes forgotten that Charles Darwin, a founding father of modern biology, was first and foremost a naturalist and that early in his life as a scientist he made important contributions to geology. In late December of 1831, the 22-year-old Darwin (1809-1882), a freshly minted graduate of Cambridge University, sailed on the British Royal Navy ship, HMS Beagle, on an around-the-world voyage of exploration and discovery. Although an avid student of the biological world, he was expected to serve also as the shipboard naturalist, and in this capacity he was given by Captain Robert FitzRoy (1805-1865) the first of three volumes of the first edition of Charles Lyell's (17971875) famous series, The Principles of Geology (1830, 1832, 1833), a landmark treatise about the rock record as interpreted in terms of present-day processes: "The present is the key to the past" (Lyell, 1830). Darwin had also received brief field training in geology from Adam Sedgewick (1785-1873) in late summer of 1831. With this limited knowledge and experience in geology, but with a keen observer's eye and a developing willingness to create conceptual models of how nature works, he explored the globe with his shipmates. In the decade after the conclusion of the Beagle's voyage in 1836, he wrote several important books and many journal articles that became founding documents in the 19th century development of the geological sciences (e.g., Darwin, $1838,1839,1842,1844,1846)$. In three of these publications (Darwin, 1838, 1839, 1844), he described several independent observations that he made during the Beagle's exploration of the Pacific coastal Andes. First, he documented the numerous formerly marine terraces raised by as much as 400 meters above sea level. These terraces were marked with shallowwater marine seashells that were indistinguishable from those living offshore and with the lower terraces having less weathered shells than the higher ones, indicating relatively recent uplift over a period of recent geologic time. On February 20, 1835, Darwin and his field assistant debarked from the Beagle at anchor in Valdivia, Chile (Yeats et al., 1997). At about 11:40 a.m. local time, a great subduction earthquake occurred offshore of south-central Chile north of Valdivia. Strong ground motion lasted two minutes; the near-shore area of the town was damaged due to the seismic sea waves, and the Beagle was hit with jarring motions as if it had run aground (Yeats et al., 1997; Herbert, 2005). With Darwin and his assistant back on board, Captain FitzRoy weighed anchor and sailed north to the source area. Dropping anchor at Talcahuano, the port town serving the city of Concepci.n, the party observed a large region of coastal uplift that was produced by the earthquake. Although these uplifts are sudden during earthquakes, such shocks occur infrequently and thus integrated over time; average uplift rates are of the order of just millimeters per year or less. Later, Darwin led a mule-pack-train exploration of the high Andes to the passes between present-day Santiago and Portillo in Chile and Mendoza, Argentina, traveling beneath the foot of Aconcagua, the highest peak in the Andes. During this journey he collected rocks with marine fossils at elevations of between 3,000 and 4,000 meters. Based on these three observations, he hypothesized that the earthquakes somehow represented the motions that raised the shorelines, produced the raised marine terraces, and slowly built the Andes mountain range (Darwin, 1839, 1844).

Darwin was not the first to make observations like these, but he apparently was among the first to put them all together. It would be decades later before it was generally understood that most tectonic cordilleras like the Andes are a consequence of horizontal compressive deformation or shortening, leading to thrust-faulting and folding that elevated continents during shortening and consequent thickening (e.g., Fisher, 1881; Suess, 1883-1909), and that continuous belts of earthquakes are often coincident with or parallel to such mountains (Mallet, 1858; Milne, 1886). It was more than a century later before it was understood that compressive deformation of continental margins is generally a consequence of subduction motion of oceanic plates as they collide with the upper plate and sink into Earth's mantle or of collisions between continents or elevated seafloor features with continents (Coats, 1962; Oliver and Isacks, 1967; Isacks et al., 1968; Dewey and Bird, 1970). Darwin's sweeping chain of logic and insightful inference has proven to be an important principle of modern investigations of the tectonics of present-day 
mountain building: earthquakes mark the places near where tectonic mountains are being built. In the context of modern digital seismology, earthquakes can be monitored anywhere in the world using global stations, complete down to about Richter magnitude 5. Satellite (GPS) measurements of earth movements also allow us to pinpoint over time where active mountain building is occurring at present. Likewise, volcanic eruptions along the spine of the Andes and volcanic cordilleras elsewhere in Latin America mark places where active mountain building by volcanic construction is taking place. These processes of active mountain building, although generally slow by human standards, can change the distribution of climatic conditions over geologic time, such as rainfall patterns and average diurnal temperatures, and other climatic factors that can potentially affect biological evolution. Moreover, Darwin noted the marked differences in biota on each side of the Andes, an observation that indicated to him that this mountain range represented a barrier to species migration. Thus Charles Darwin's early work as an insightful pioneer in geology also has a direct bearing on our understanding of one of the causes of environmental change that, in turn, is one of the principal drivers for speciation and biological evolution through natural selection that he also pioneered along with Alfred Wallace (Darwin, 1858; 1859, 1862; Wallace, 1858, 1870, 1889).

This paper is a preliminary exploration of these concepts as applied to southeast Mexico and Central America during the bicentenary year of Darwin's birth and the 150th anniversary of the publication of Origin of Species. It is intended as a preliminary application of knowledge of the tectonic and volcanic events of this region that is possibly relevant to the geologically recent changes in environmental conditions that may have shaped in part the distribution of orchid species and their evolution during the same period of geologic time of the evolution of our own genus, Homo, in Africa.

\section{Southeast Central America: a hotspot of orchid diversity}

The status of southeast Central America as a biological hotspot has long been recognized (see reviews by Dressler, 1985; Burger, 1985; Myers et al., 2000; Ossenbach, 2009). Although there are strong differences in the likely degree of undersampling of

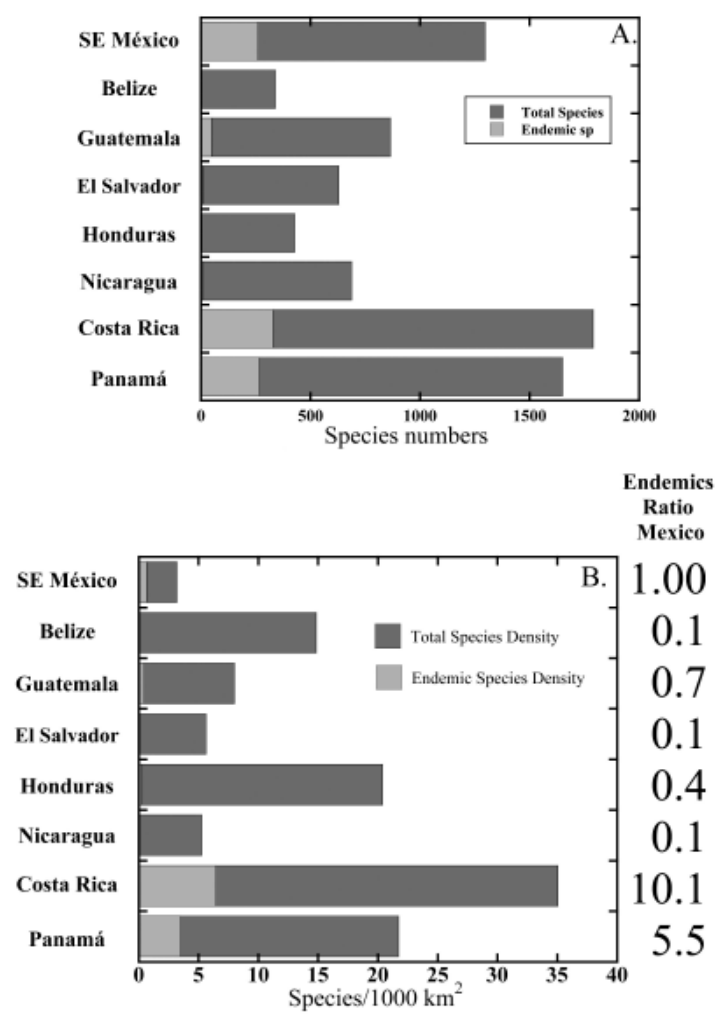

FIgURE 1. Distribution of orchid species numbers by geographic area (data source: Ossenbach et al. (2007)). A. Total species and endemic species numbers by country. B. Species per $1000 \mathrm{~km}^{2}$ country area (species density) for both total species and endemic species.

orchid flora and the degree of deforestation and habitat loss by country, the data from a recent checklist of orchid species distribution in Central America and southeast Mexico show that differences in total orchid diversity and endemic species per country area (Fig. 1A, B) are extremely large (Ossenbach et al., 2007), probably more than expected due to differences in the degree of undersampling. In particular, the species inventories of Costa Rica and Panama show manifold area density contrasts with the rest of tropical America in the Northern Hemisphere. In general, country borders are usually not natural biogeographic boundaries, but orchid species distributions are often known only to the country level, so we are forced in our analysis to restrict ourselves to this crude breakdown. Nonetheless, there are stark differences between the large area densities of endemic orchid species of Costa Rica and Panama with their cordilleras and intermontane valleys on the 


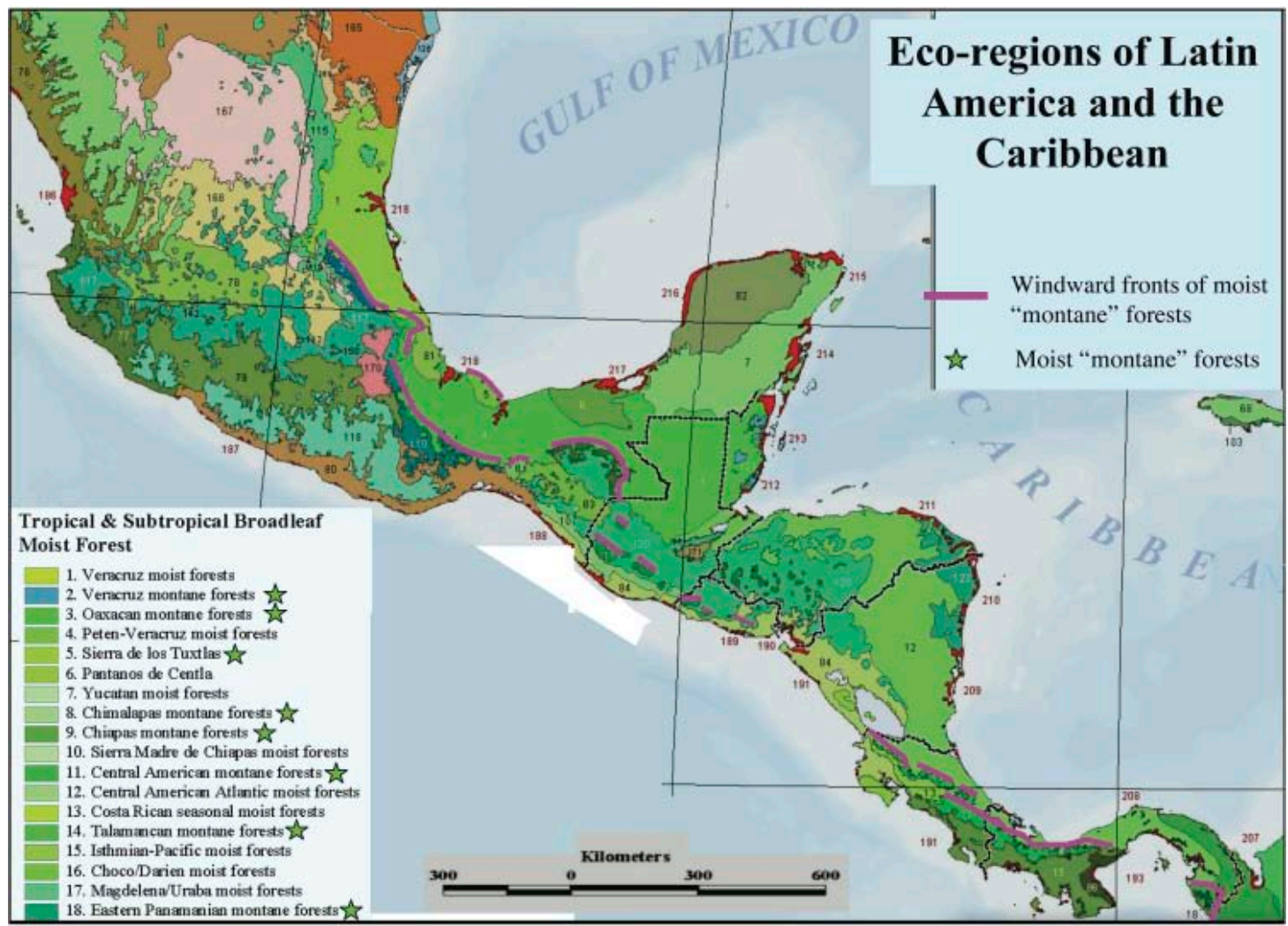

Figure 2. Map showing the eco-regions of Central America and southeast Mexico with emphasis on moist, broadleaf, tropical/subtropical forests. Magenta lines mark the approximate windward fronts of wet upland life zones. Modified from the online Nature Conservancy Landscape Ecology Program Map: "Ecoregions of Latin America and the Caribbean" [Dienerstein et al. (2001)].

one hand and the low species densities of the largely lowland countries of Nicaragua, El Salvador, and Belize, differences that are impressive and probably transcend sampling biases. An important question is why such differences exist, an enigma that is the subject of this paper, one that builds on the work of Dodson (2003) concerning origins of the diversity of orchids in Ecuador. His hypotheses are largely echoed and amplified in the present paper and applied to southeast Central America.

\section{Mountain belts, geological processes, and biological diversity}

It is well established that wet tropical premontane to montane life zones are among the most diverse and biologically exuberant regions in the world (e.g., Holdridge, 1947, 1967; Hall and Brignoli, 2003; Ossenbach, 2009). By implication, such zones are also crucibles for biological evolution. Mountains create regional climatic conditions through the orographic effects of adiabatic cooling of moist air moving upslope that increase rainfall and also the effects of enhanced radiative cooling of thinner atmospheres at higher elevations in moderating tropical temperatures and promoting plant growth. The mountain belts in Central America form discontinuous curvilinear belts of moist premontane to montane forests from southern Mexico to Panama (Fig. 2).

I discuss below other effects of mountain chains (and processes that occur in them) on the biogeography of tropical orchids within the Americas in the context of the major governing biogeographic processes: dispersal, speciation, and extinction (Fig. 3). I consider these processes in this context of the ensemble of orchid species and their biological cohorts — their pollinators and the mycorrhizal fungi that 


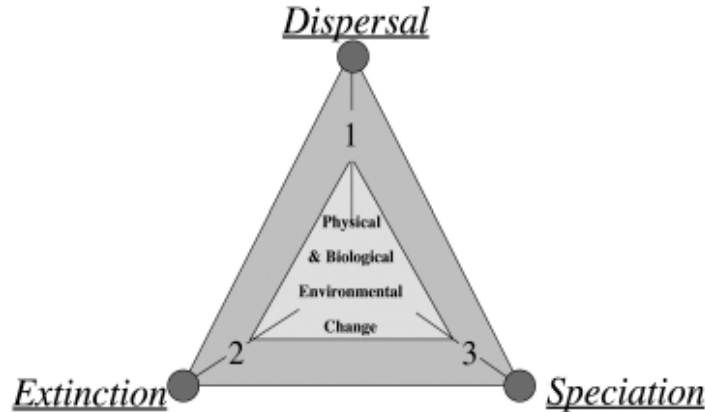

FIGURE 3. Schematic ternary diagram depicting graphically the links (1, 2, and 3 ) between the drivers of evolution of biota (physical and biological changes) and the processes that control the biogeography of life forms: dispersal, speciation, and extinction. See text for discussion.

enable them to germinate. It should be understood that any biogeographic conclusions reached in this report pertain to the ensemble of these cohorts.

The spectrum of active geological processes, environmental change, and evolution: dispersal, extinction, and speciation

Dispersal-That mountain belts serve as partial barriers or 'filters' to gene flow of orchid species adapted to lowland tropical conditions is obvious from inspection of the orchid flora of countries of the tropical Americas, especially in differences between the flora of the Caribbean and Pacific slopes in Central America and the Atlantic (Amazonian) and Pacific slopes in South America. Mountains in the tropics represent more effective filters to migration of species adapted to lowland conditions, because lowland tropical species are not forced to adapt to large seasonal temperature fluctuations as lowland plants must at high latitudes, i.e., in the tropics, montane and lowland temperatures do not overlap with changes in the seasons (Janzen, 1967). Conversely, hot, dry lowlands interrupting mountain chains can serve as partial barriers to dispersal of orchid species adapted to cool, moist highland conditions. I use this term 'partial' in light of rare, long-distance orchid dispersal events that have led to occurrence of orchid species on Cocos Island, some $530 \mathrm{~km}$ from mainland Costa Rica, some of which are endemic to the island and some found elsewhere in Central America and Peru (Trusty and Blanco, 2005; Trusty et al., 2006).

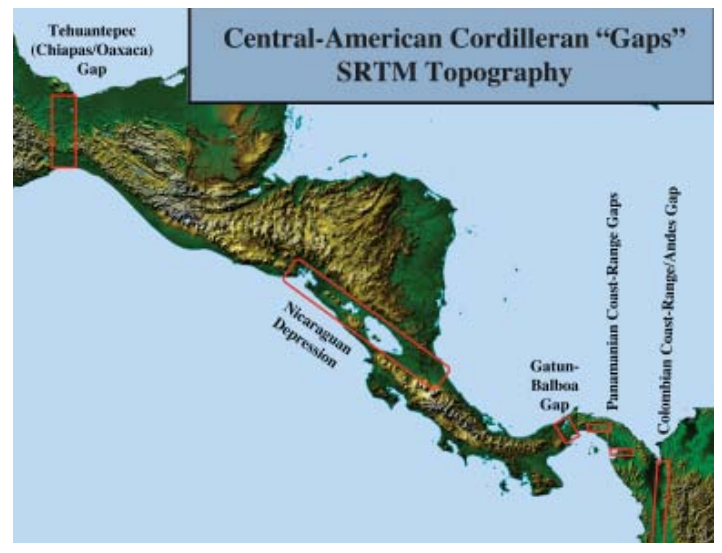

Figure 4. Color-shaded relief topography of southeast Mexico, Central America, and northwest Colombia showing the principal lowland gaps between cordilleras.

The major lowlands that interrupt southeast Mexican and Central American cordilleras are from north to south (Fig. 4): 1) the Tehuantepec (Chiapas/Oaxaca) gap; 2) the Nicaraguan depression; 3) the GatunBalboa gap crossed by the Panama Canal; 4) the valley of the R.o Chepo that separates the Pacific and Caribbean coast ranges in eastern Panama; 5) the R.o Chucuaque/Gulf of San Miguel gap; and 6) the near-coastal Colombian lowland between the Gulf of Urab. and Buenaventura Bay in Colombia that separates the Pacific coast ranges of Panama and northwest Colombia from the main Andean cordillera (the Cordillera Oriental). The Nicaraguan depression is easily the most prominent lowland gap among mountain ranges in Central America based on its width and the fact that some of this lowland is occupied by the lowland Lakes Nicaragua and Managua and the Gulf of Fonseca that are at or near sea level. This depression is a rift structure associated with extension and subsidence (Phipps Morgan et al., 2008; Funk et al., 2009). In fact, the distribution of elevated beach lines above the present lake levels indicate that a broad inland seaway that connected these bodies of water existed as recently at 6,000 years before present (Roberto Protti, personal communication, January 2009). The arc volcanoes of Nicaragua are also among the lowest along the main Central American volcanic arc. On a more local scale, valleys between volcanic mountains can be many hundreds of meters lower in elevation than their peaks, as they are in the Central Volcanic Range in Costa Rica. It is not known if these 
inter-volcano valleys are effective in filtering orchid gene flow. The possible impacts of regional lowlands will be discussed after interpreting distributions of taxa of Maxillariinae by country.

Speciation-Speciation is dominantly a biological process but one that can be influenced by environmental factors. Mutagenesis, the production of new biological forms with inheritable traits, is caused by damage to the nucleotide sequence of organisms and is affected by exposure to chemicals, high-energy radiation from natural decay products of radiogenic nuclides in nature, ultraviolet solar radiation, and cosmic rays from space. Mutations provide the inheritable variability that, when acted upon by geographic, environmental or sexual isolation, can lead to new species that do not cross with their forebears or closely related kin (Dodson and Gillespie, 1967). Mountain building clearly can cause geographic and environmental isolation.

It is often assumed that exposures to mutagens are random (and associated with normal biological processes such as cell division), that rates of genetic change are essentially constant, and hence that branching of the tree of life can be accurately dated by this genetic molecular clock. However, exposures to such mutagens can be spatially non-random. Ultraviolet and cosmic radiation have higher fluxes at higher elevations due to less screening by thinner atmospheres. Volcanoes produce a toxic brew of chemicals in gaseous form ( $\mathrm{SO} 2, \mathrm{CO} 2, \mathrm{HCl}, \mathrm{HF}$, and radon) that can also interact in the atmosphere to produce sulfuric, carbonic, hydrochloric, and hydrofluoric acids, and other chemically aggressive species; these chemicals can kill plants and create dangers to human health. It is not known if sub-lethal exposures of these chemicals can induce mutagenesis in plants, a question that could be answered by experiment. Similarly, rocks vary widely in the levels of radioactive elements in their minerals, such as uranium, thorium, potassium (K40), and radon. Some granites and volcanic rocks found in mountain ranges have high enough radioactivity to pose potential health risks with long exposure. These examples might indicate that mutagenesis may not be spatially random and could occur at higher rates in tropical highlands. This possibility should be investigated in long-term experiments. Putting the question another way, such experiments would answer the interesting question:
Does the DNA molecular clock always run true (at a uniform rate) or does its going rate vary geographically and faster in some mountain ranges?

Extinction-As natural agents of destruction of habitats and life, volcanoes and volcanic eruptions are difficult to match in scale and within the spectrum of destructive volcanic processes (Baxter, 2000). Effusive volcanic eruptions are those involving non-explosive extrusions of magma to form lava flows, lava domes, and flood basalts. Lava flows are guided by topographic lows and can fill valleys and rivers, destroying whole riparian ecosystems. Dodson (2003) described such an event in Ecuador and its effects on valley orchid populations. Flood basalts can cover enormous areas, from hundreds to half a million square kilometers (Mahoney and Coffin, 1997). Unquestionably, events in this size range have caused biotic extinctions of species endemic to those areas and have probably been effective in interrupting orchid dispersal in the geologic past.

Giant explosive volcanic eruptions (sometimes called 'super eruptions") can have much more widespread and manifold effects on conditions for life on Earth (Mason et al., 2004). Such eruptions can launch columns of hot tephra (ash) and gas as high as $50 \mathrm{~km}$ into the stratosphere. Volcanic aerosols suspended high in the atmosphere after the largest explosive eruptions have significantly cooled the planet for periods of months to years after the causative eruption. Global-scale volcanic crises are well documented in ice cores drilled from ice sheets in Greenland and Antarctica. Sequences of such eruptions may have cooled Earth for longer periods of time and hence had global climate impacts that are likely to have led to some extinctions of life forms due to multi-year cooling. Luckily, 'super' eruptions of this size have not occurred during historical times. However, the geologic record is marked by evidence for many giant explosive eruptions in Cenozoic time (the past $\sim 65$ million years). This evidence includes the formation of large volcanic calderas, features caused by large eruptions of magma associated with largevolume eruptions that lead to collapse of near-surface crust. Dozens of late-Cenozoic calderas with diameters greater than $5 \mathrm{~km}$ have been recognized in tropical Latin America. Another geologic indicator of the scope of explosive eruptions is in the distribution of ignimbrites (ash-flow sheets) that are products of collapse of the 
hot eruption plume, a phenomenon called base surge, leading to pyroclastic flows of hot gas and tephra from the vent that can blanket areas as great as hundreds to tens of thousands of square kilometers and rock volumes of hundreds of cubic kilometers. Large ignimbrite fields of late Cenozoic age are common in Latin America, and such events probably led to destruction of large areas of forest cover and likely many regional extinctions of narrowly endemic orchids in the past. Repopulation of forests in the tropics can be fairly rapid given the high rainfall and the fertility of volcanic soils. In fact, Anak Krakatau, the island in the Sunda Straight left after the cataclysmic 1883 eruption in Indonesia, now has a dense tropical forest in place (Simkin and Fiske, 1983).

Valley-filling lahars (volcanic mud flows) can devastate lowlands and valleys near volcanoes and probably caused extinctions of narrow endemics in valley habitats in the American tropics similar to the effects of valley-filling lava flows and pyroclastic flows. Volcanic gases that boil out of magmas as they ascend to the surface during eruptions interact with atmospheric water to make acid rain and VOG (a ground-hugging volcanic fog) downwind from eruptive centers. Under certain conditions during prolonged eruptions, VOG can drift hundreds of kilometers from its source volcanic vent; volcanic phenomena have affected human health and have led to forest and cropland destruction. Moreover, volcanic eruptions can provide vital scientific information: they can be accurately dated from the isotopic makeup of the radioactive elements in some minerals that comprise volcanic rocks. These dates, in turn, can tell us when possible extinction events occurred or when geographic separation might have taken place between orchid populations. Chronologies of environmental events such as these may help establish absolute time marks on molecular clocks.

\section{Young geological history of Costa Rica and Panama}

The mountains in Costa Rica and Panama are, along with those in western Colombia and certain cordilleras in Ecuador and Peru, among the youngest in tropical Latin America. This condition is largely a consequence of the nexus of six moving tectonic plates and five trenches (where oceanic plates dive into Earth's mantle) in that region, and two major volcanic ridges (Cocos and Carnegie Ridges) that originate at the Galapagos hotspot and recently began colliding with the Pacific margins of Costa Rica, Panama, Colombia, and Ecuador (Fig. 5; Mann and Corrigan, 1990; Mann, 1995; Coates, 1997; Wallace, 1997; Denyer et al., 2003; Harmon, 2005; Mann et al., 2006; Sak et al., 2009). In a recent review of the chronologies of the volcanic and tectonic mountain ranges in Costa Rica, Denyer and Alvarado (2007) documented the remarkably young ages of the major phases of mountain building of these cordilleras (Table 1, Fig. 6), ranging from the Guanacaste and Central Volcanic Ranges $(<0.5$ Ma BP [million years before present]) and the Fila Costeña (Pacific Coast Range) at $<<2$ Ma BP, 5 Ma BP for Cordillera Tilarán, and 4-10 Ma BP for the main Talamanca Range that extends into Panama and forms the mountainous backbone of both countries (sparsely distributed older igneous rocks in the Talamanca may represent the roots of earlier island-arc volcanoes). Recent research indicates that the Talamanca Range has its highest elevations in Costa Rica as a consequence of underthrusting in the former forearc basin rocks of the Fila Costeña under the Talamanca, a process that started no earlier than 2 Ma BP (Fisher et al., 2004; Morell et al., 2007; Steichler et al., 2007; Donald Fisher, personal communication, October 2009; Sak et al., 2009). Thus the highest mountain range in Costa Rica and Panama was probably uplifted to its present elevation during Quaternary time (recently redefined as younger than 2.6 Ma BP).

These cordilleras are among the youngest mountain ranges in the world and were largely built during the time when our own species in the genus Homo evolved. Costa Rica and Panama are the youngest products of continent and mountain building in tropical Latin America. This region was formerly an oceanic seaway that was dotted by an island arc (subduction volcanic island chain) as recently as late Cenozoic times (25 Ma) and evidently at least served as partial barriers to the earlier dispersal of plant and animal species, famous in the annals of biogeography for the later great faunal exchange that was in full force by the beginning of Quaternary time (2.6 Ma BP; Webb, 1997). The gradual closing of this seaway by sediment accumulation and mountain building between present-day Colombia and the rest of Central America began about $12 \mathrm{Ma} \mathrm{BP}$ and was completed about 3 to $4.2 \mathrm{Ma} \mathrm{BP}$, based mainly on evidence from marine biogeography and salinity that were recorded in marine sediments that provided a chronology of ocean circulation through the seaway 


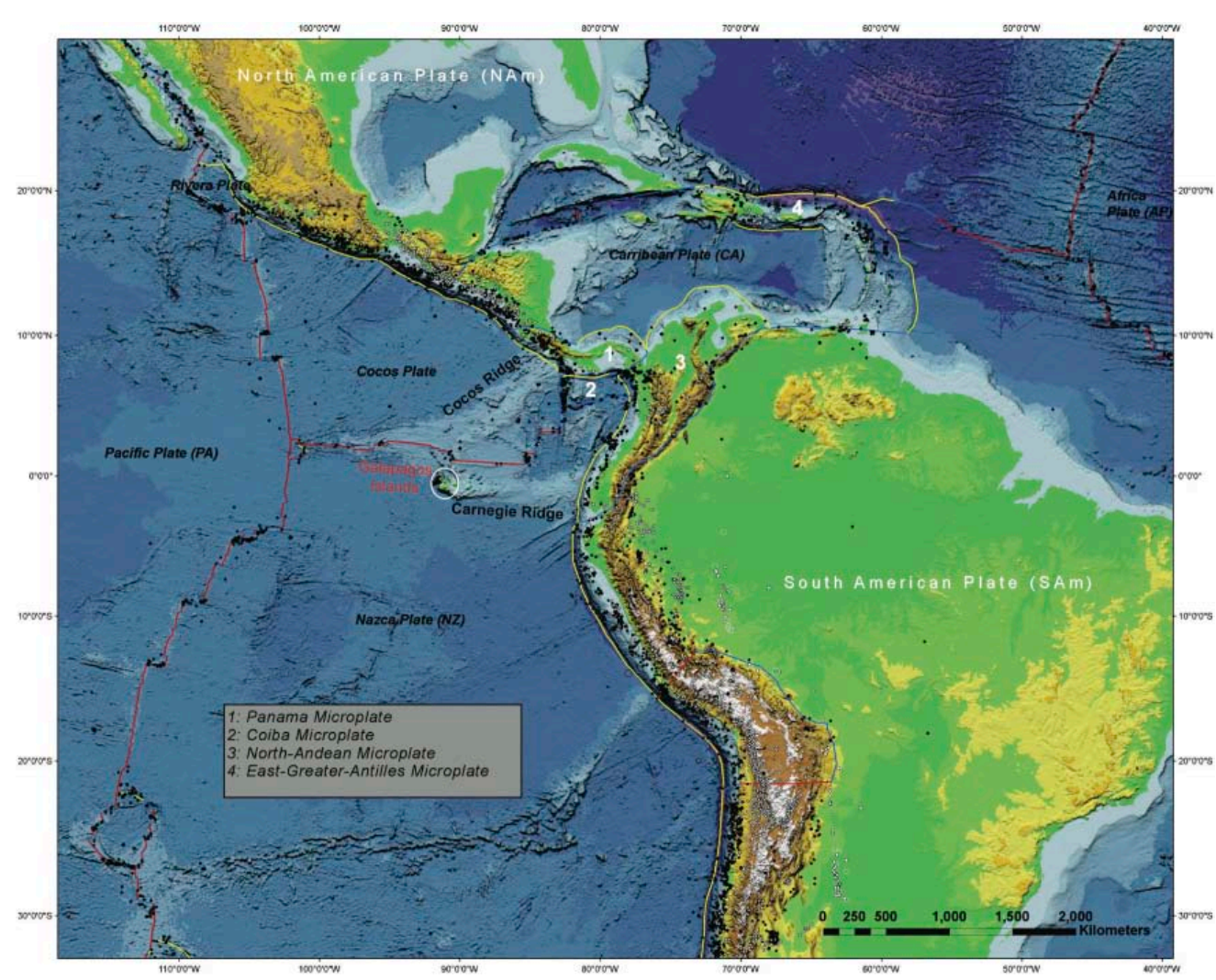

FIGURE 5. Plate-tectonics map of tropical America, including plate names and plate boundaries. Also shown are locations of volcanoes and volcanic centers (red triangles), earthquake epicenters (dots) and volcanic ridges originating at the Galapagos hotspot. This region is tectonically active, where landscapes and physical environments have been changing rapidly during Cenozoic time. Adapted from Simkin et al. (2006).

between the Atlantic-Ocean/Caribbean-Sea and the Pacific Ocean (e.g., Haug et al., 2001).

Figure 2 shows the distribution of moist, tropical, broadleaf montane forests in Central America based on the Nature Conservancy "Map of the Eco Regions of Latin America." I have highlighted on this map the windward fronts of mountain ranges, based on presentday prevailing wind patterns, that mark the northeast margins of moist, broadleaf montane forests in Central America and tropical Mexico. This map clearly shows that the total lengths and areas of such eco-regions in Mexico exceed those in Costa Rica and Panama. However, mountain building — tectonic and volcanic - in present-day tropical Mexico is far less active than in Costa Rica; the cordilleras in that part of tropical Mexico are far older that those in Costa Rica and Panama, and arc volcanoes are more sparse compared to the closely spaced volcanoes in the continuous volcanic chain from Guatemala to southern Costa Rica. The central highlands of Honduras show similarities to those of southern Mexico. Geologically speaking, the rocks of the central Honduran highlands are pre-Cenozoic (older than about $65 \mathrm{Ma}$ ) and represent rocks accreted to the Central American isthmus over hundreds of millions of years (Rogers et al., 2007). Instead of curvilinear cordilleras, most of these highlands are isolated mountains representing rock types that are resistant to erosion; many of these uplands are dominated by Pinus species. The presentday seismicity rate is also low in Honduras. Belize and Nicaragua support mostly lowland forest. Although Guatemala and El Salvador have active high volcanic cordilleras near their Pacific coasts, much of their forests are in lowlands. Finally, the Central American isthmus is narrowest in Costa Rica and Panama, and orographic effects of mountains tend to distribute 
TABLE 1. Core Maxillariinae cladogram (Whitten et al., 2007). Estimated total species numbers and established species counts in each genus from Blanco et al. (2007).

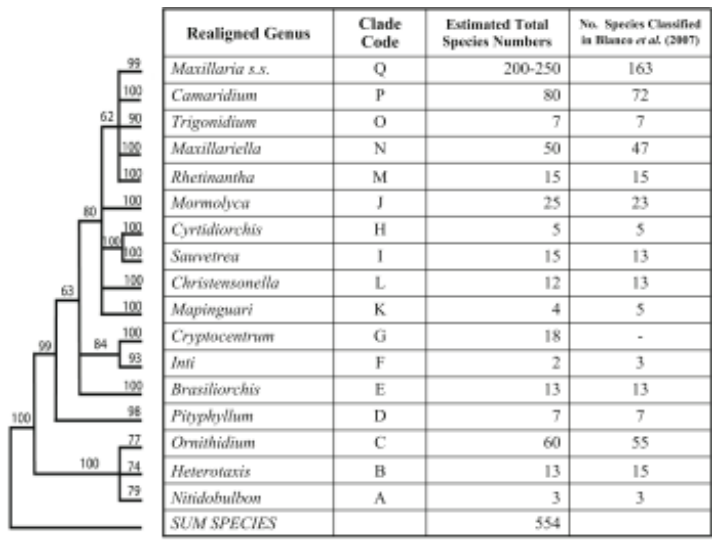

rainfall over a much narrower area of the highland isthmus than farther north.

The foregoing observations show that the presentday distribution of tropical cloud forest environments alone does not explain why so many more orchid species are endemic to the southernmost countries of Central America, where orchid diversity tends to be most exuberant. Of course, the latter are at lower latitude than tropical regions farther north, and perhaps higher average temperatures and greater rainfalls may be playing roles in these differences in orchid diversity. However, tradeoffs of warmer conditions at lower elevation ranges may negate the lower temperatures at higher latitudes. For many orchid tribes, centers of diversity are in South America, such that presentday orchid species distribution may be a snapshot of a general trend toward northward dispersal from these centers. In light of these observations, I consider two working hypotheses in this study: 1) hotter and drier lowland gaps between the cordilleras of Central America reduce the rates of this northward dispersal of species adapted to highland conditions (and possibly the southeasterly counter gene flow of species endemic to northern Central America), and 2) high rates of environmental change connected with mountain building in late Cenozoic times are significant factors in promoting more rapid orchid speciation in Costa Rica and Panama. These biologically important factors associated with mountain building are applied to the country distribution data for core Maxillariinae in Central America and southern Mexico.

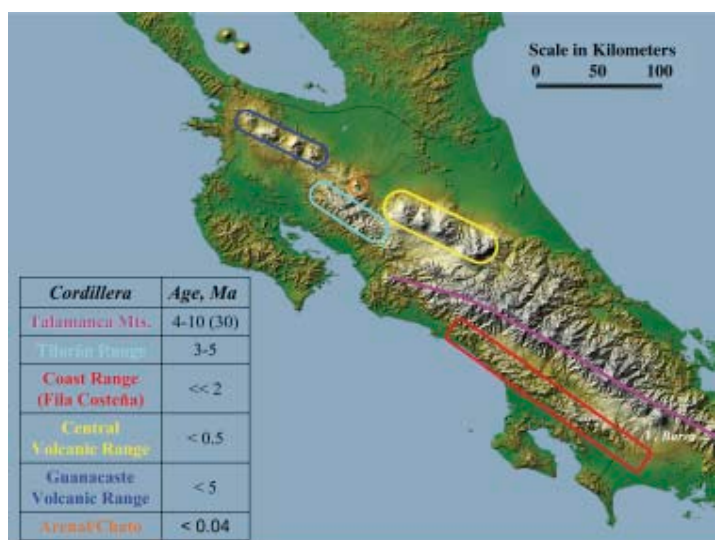

Figure 6. Color-shaded relief map of Costa Rica showing the locations of the principal mountain ranges, their approximate ages, and active and recently active volcanoes (inset). Based on Denyer et al. (2003), Denyer and Alvarado (2007), and information from Donald Fisher (Pennsylvania State University, personal communication, October 2009).

\section{A case study: distribution of Maxillariinae in Southeast Mexico and Central America and adjoining regions}

Data and methodology-To explore the abovementioned working hypothesis, I have analyzed the distribution of species in core Maxillariinae in Central America. There are several reasons that these are good taxa to use. There is a large number of species (550- 580) according to Whitten et al. (2007) and Alrich and Higgins (2008). Most of these species are relatively large, conspicuous, and locally abundant. These species have diverse flower and plant traits and display a range of pollination syndromes. Ossenbach et al. (2007) documented 160 species in Central America and tropical Mexico (the states of Chiapas, Tabasco, Veracruz, and Puebla). Members of these taxa are found in all of the countries of South America and the Antilles over a wide range of elevations. Finally, this group of species has received the attention of a recent and extensive molecular phylogenetic study by Whitten et al. (2007) using multiple molecular markers, resulting in a well-supported generic realignment of the subtribe into 17 clades (Table 1). This was followed up by a reclassification of the subtribe by Blanco et al. (2007) based on the molecular data and phenotypical characters described by Whitten et al. (2007). 
My starting point for country distribution data on species in core Maxillariinae are the checklists by Ossenbach et al. (2007) and Atwood (2003). I supplemented these resources with the following online herbarium data resources: Tropicos (Missouri Botanical Garden), INBIO, Lankester Botanical Gardens Epidendra database, the Costa Rica National Herbarium, and the Worldwide Checklist of Monocotyledons. To resolve questions of synonymy, I largely relied on the assessments in the online Tropicos checklist and papers by Atwood and Mora de Retana (1999) on the subtribe. For Central American nations, I also relied on the most recent orchid monographs by countries listed below in Literature Cited. For tropical Mexico, I also consulted Soto et al. (2007) and H.gsater et al. (2005). In the interest of exploring distribution differences between Central and South America, I checked the distribution of species found in Central America and tropical Mexico that have also been collected in South America and the Antilles by consulting Misas-Urreta (2005) for nearcoastal northwest Colombia; an unpublished database of herbarium collections by Dodson for Ecuador as well as his splendid five-volume book series (2000-2004); a checklist by Dodson of Colombian Maxillaria species in Ospina (1996); the four-volume book series Native Colombian Orchids edited by Escobar (1990) and Dodson (2002, 2003b); Zelenko and Bermudez (2009) for Peru; McLeish et al. (1995) for Belize; Dunsterville and Garay (1979) for Venezuela; and Nir (2000) for the Antilles. In cases of differences in distribution data between sources, my preference was generally to adopt distribution data for vouchered herbarium specimens that were collected and identified in recent decades. Many ambiguities exist in this distribution database, for which some of my choices may have been in some cases somewhat subjective and arbitrary. Elevation data for specimen collection were generally taken as those reported except where geographic locations were incompatible with the stated elevations. All of these summaries of the orchid flora suffer from varying degrees of undersampling. Of particular concern is undersampling in northwest Colombia and eastern Panama due to security challenges, a shortcoming that may bias assessments of the distribution data of species common to both Central and South America.

Country abbreviations in this study are as follows: Bolivia (Bo), Peru (Pe), Ecuador (Ec), Colombia (Co),
Panama (Pa), Costa Rica (CR), Nicaragua (N), El Salvador (ES), Honduras (H), Guatemala (Gu), Belize $(\mathrm{Be})$, Mexico (Mx), Greater Antilles (GA, including southern Florida, USA), Lesser Antilles (LA), Guyana (Gy), and Venezuela (V).

\section{Results}

Geographic distribution-The country distribution data were classified according to the following scheme based on the distribution patterns that were evident (Table 2):

Class 1: Species endemic to Costa Rica and/or Panama (Southeast Central America - SE CAm) $[83$ species in this class]

Class 2: Species endemic to both SE CAm and at least two countries in northern Central America $(\mathrm{N}$ CAm) [Nicaragua, Honduras, Guatemala, \pm Mexico \pm Belize and \pm El Salvador [13 species]

Class 3: Species endemic to both SE CAm and northwest South America (Colombia, Venezuela, Ecuador, Peru) [31 species]

Class 4. Species endemic to N CAm [9 species]

Class 5: Pan Latin America (N CAm and SE CAm and NW S Am) [18 species]

Class 6: Occurrence in Ossenbach et al. (2007) not verified in CAm in this study but reportedly found in SAm [6 species].

TABLE 2. Classification scheme of country distribution of core Maxillarinae species reported in Central America according to their north-south geographic spread by country in tropical Latin America. Notes: $\pm=$ may or may not be present; * Distribution Code 1: Pa and/or CR; Code 2: $\mathrm{Pa}$ and/or CR + two or more NW CAm countries; Code 3: $\mathrm{Pa}$ and/or CR +2 or more of Co, Ec, or Pe; Code 4: 2 or more $\mathrm{N}, \mathrm{Gu}$, or Mx; Code 5: SE CAm +2 or more NW $\mathrm{CAm}+2$ or more NW CAm.

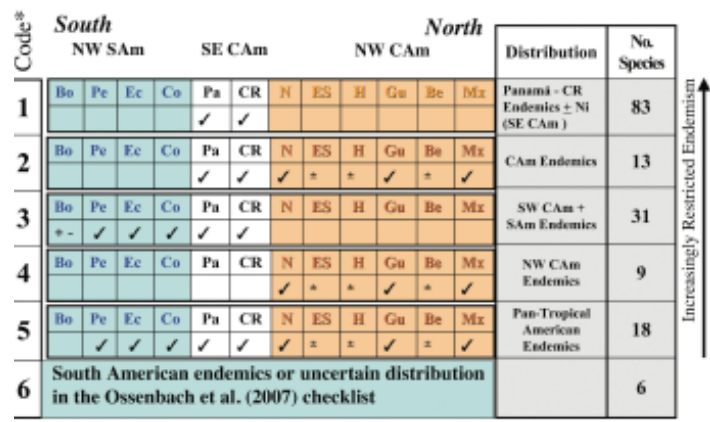




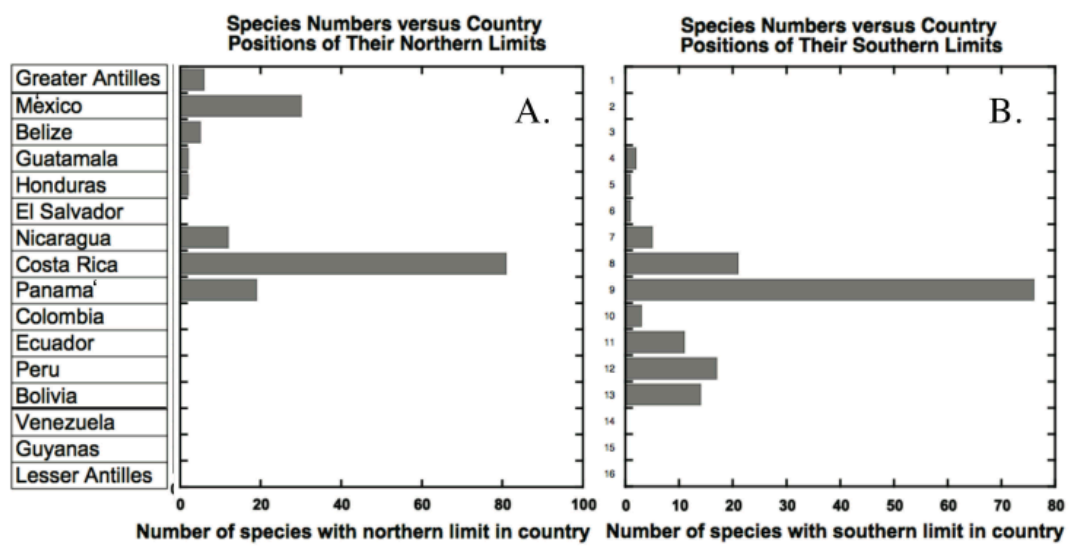

FIGURE 7. Histograms showing the northern and southern limits of geographic ranges of core Maxillariinae species occurring in Central America. A. Northern limits by country. B. Southern limits by country.

Several observations may be made concerning species levels in these geographic classes. First, Costa Rica and Panama have by far the greatest number of endemic species among Central American nations and tropical Mexico, a finding that mirrors the overall level of orchid species endemics among these nations and one that has been recognized earlier by others based on more limited data. However, as discussed below, this result is weighted heavily in just a few clades recognized in the Whitten et al. (2007) study. Second, more species in Maxillariinae in Costa Rica and Panama have species in common with South America (31) than other countries in Central America and tropical Mexico (13). Combined with the fact that nearly three-quarters of all species in Maxillariinae are found only in South America indicates that the primary ancestral evolutionary center for the subtribe was on that continent, with a secondary center in Costa Rica and Panama and with lesser endemism in northern Central America, tropical Mexico, and the Antilles.

It is also useful to examine the northern and southern geographic limits by country of species in this taxa for species that occur in Central America and tropical Mexico (Fig. 7). By far, the largest number of species have northern limits in Costa Rica (Fig. 7A) and southern limits in Panama (Fig. 7B). This finding follows from the high number of endemics in these two countries. Thirty species have northern limits in Mexico, perhaps reflecting a somewhat lower total number of Mexican endemics (Fig. 7A), the northern limits of tropical climate, and also the longer potential dispersal distance to the Greater Antilles and southern Florida. Few species in this tribe have northern or southern limits in Belize, Guatemala, El Salvador or Honduras.

Elevational distribution - I show the distribution of species in Maxillariinae with elevation range in Figures 8 and 9 for two of the six distribution classes studied. Class 1 species (83 total), those with the narrowest distribution, tend to have elevation limits of $500 \mathrm{~m}$ or above; these are clearly species (74 in number) mostly adapted to the cooler and wetter conditions found in the cloud-forest highlands of Costa Rica and Panama (Fig. 8A, 9A). There are nine exceptions to this trend: species that are restricted to Costa Rica and/ or Panama and also have their lower elevation limits below $200 \mathrm{~m}$ (Camaridium suaveolens (Barringer) M.A.Blanco, Maxillariella diuturna (Ames \& C.Schweinf.) M.A.Blanco, Mormolyca dressleriana (Carnevali \& J.T.Atwood) M.A.Blanco, Maxillaria endresii Rchb.f., Ornithidium nicaraguense (Hamer \& Garay) M.A.Blanco \& Ojeda, Maxillariella oreocharis (Schltr.) M.A.Blanco \& Carnevali, Camaridium latifolium Schltr., Maxillariella sanguinea (Rolfe) M.A. Blanco \& Carnevali, and Camaridium vittariifolium (L.O.Williams) M.A.Blanco according to the realignments by Whitten et al. (2007) and Blanco et al. (2007). Finally, no species in this geographic distribution class shows an elevation range greater than about $2000 \mathrm{~m}$ above their lowest reported elevation, an interesting limitation that may have a physiological 


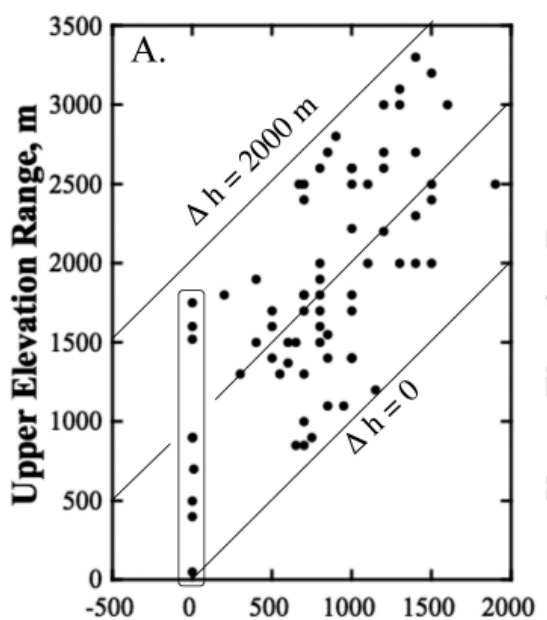

Lower Elevation Range, $m$

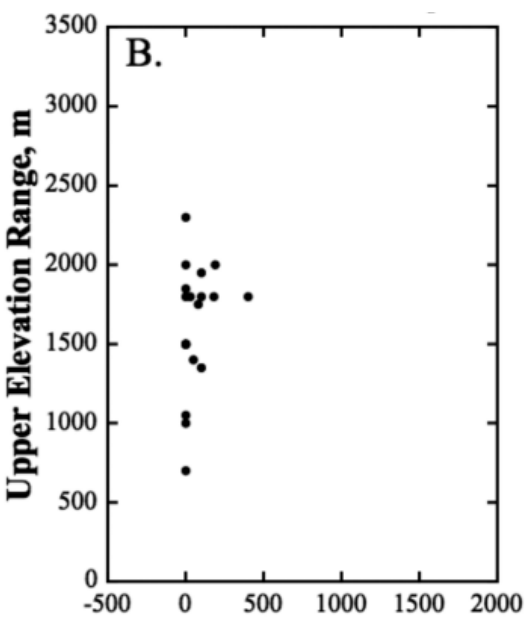

Lower Elevation Range, $m$

FIgURE 8. Elevation ranges for core Maxillariinae species plotted as lower elevation limit on the horizontal axis versus upper elevation limit on the vertical axis. A. Geographic Class 1 species (Costa Rica and/or Panama endemics). $\Delta \mathrm{h}$ is the elevation range. Note that most of these species have lower elevation limits greater than $500 \mathrm{~m}$. Species that are exceptions enclosed by the vertical box are listed in the text. B. Class 5 species (Pan Latin American species, all lowland).
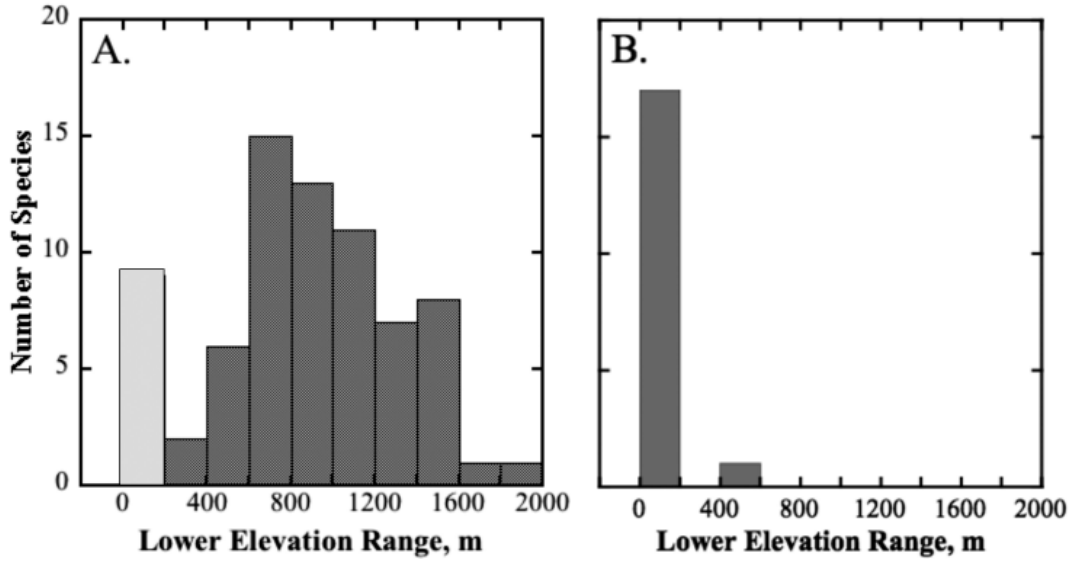

FIGURE 9. Comparisons between the histograms of the lower elevation limits for core Maxillariinae species for two different geographic distributions. A. Class 1 species (Costa Rica and/or Panama endemics), largely upland species with exceptions noted in text (light gray) B. Class 5 species: Pan Latin American species, all extending to low elevations.

origin. For Class 5 species, the Pan Latin American ones, all 18 have lower elevation limits below 500 and most (17) below $200 \mathrm{~m}$ (Fig. 8B, 9B). The wide geographic distribution of this class indicates that part of their successful dispersal may be rooted in their evident adaptation to lowland conditions and hence easier dispersal than those adapted to exclusively higher elevation ranges and likely subject to strong dispersal 'filters' across generally hot, dry lowland gaps between cordilleras.
Geographic distribution of clades-Table 3 summarizes the distribution of the clades of Whitten et al. (2007) among the geographic distribution classes identified in this study. Summing the species numbers for classes 1 through 5 shows that Camaridium is easily the most abundant genus of core Maxillariinae in Central America, representing 62 of the total of 72 species that Blanco et al. (2007) recognized in this genus. This important genus of tropical epiphytes represents about $15 \%$ of all species in the core Maxillariinae and 
TABLE 3. Geographic distribution of species in core Maxillariinae following Whitten et al. (2007) and Blanco et al. (2007). See notes in text and at bottom of this table.

\begin{tabular}{|c|c|c|c|c|c|c|c|c|c|}
\hline Clade & Clade/Genus Name & 1 & 2 & 3 & 4 & 5 & Sum 1 thru 5 & $\begin{array}{l}\text { All Latin } \\
\text { America }\end{array}$ & $\begin{array}{c}\text { \% Species in } \\
\text { Central America }\end{array}$ \\
\hline Code $^{\wedge}$ & $\begin{array}{l}\text { Geographic } \\
\text { Classes } \rightarrow\end{array}$ & $\begin{array}{c}\text { SE CAm- } \\
\mathrm{CR}+\mathrm{Pa} \\
\end{array}$ & \begin{tabular}{|c|} 
Pan CAm - N \\
\& SE CAm \\
\end{tabular} & $\begin{array}{l}\mathrm{SECAm}+ \\
\text { SAm } \\
\end{array}$ & NCAm & Pan LAm & & $\begin{array}{c}\text { Blanco et al. } \\
(2007)^{*}\end{array}$ & \\
\hline $\mathrm{A}$ & Nitidobulbon & & & & & 1 & 1 & 3 & 33 \\
\hline B & Heterotaxis & & 1 & & & 3 & 4 & 15 & 27 \\
\hline $\mathrm{C}$ & Ornithidium & 4 & & 1 & 1 & 1 & 7 & 55 & 13 \\
\hline $\mathrm{D}$ & Pityphyllum & & & & & & 0 & 7 & 0 \\
\hline$E$ & Brasiliorchis & & & & & & 0 & 13 & 0 \\
\hline $\mathrm{F}$ & Inti & & & 2 & & & 2 & 2 & 100 \\
\hline $\mathrm{G}$ & Cryptocentrum & 3 & & 4 & & & 7 & 18 & 39 \\
\hline $\mathrm{H}$ & Cyrtidiorchis & & & & & & 0 & 5 & 0 \\
\hline $\mathrm{I}$ & Sauvetrea & 1 & & & & & 1 & 13 & 8 \\
\hline $\mathrm{J}$ & Mormolyca & 1 & 2 & & & 1 & 4 & 23 & 17 \\
\hline $\mathrm{K}$ & Mapinguari & & & 1 & & & 1 & 5 & 20 \\
\hline $\mathrm{L}$ & Christensonella & & & & & 1 & 1 & 13 & 8 \\
\hline $\mathrm{M}$ & Rhetinantha & 1 & 1 & & & 2 & 4 & 15 & 27 \\
\hline $\mathrm{N}$ & Maxillariella & 5 & 3 & 2 & 2 & 3 & 15 & 47 & 32 \\
\hline $\mathrm{O}$ & Trigonidium & 1 & & 2 & & 1 & 4 & 7 & 57 \\
\hline $\mathrm{P}$ & Camaridium & 52 & 3 & 3 & 1 & 3 & 62 & 72 & 86 \\
\hline$Q$ & Maxillaria s.s. & 11 & 2 & 11 & 4 & 1 & 29 & 163 & 18 \\
\hline & SUMS -> & 79 & 12 & 26 & 8 & 17 & 142 & 476 & 30 \\
\hline \multicolumn{10}{|c|}{ A As coded by Whitten et al. (2007) } \\
\hline \multicolumn{10}{|c|}{ "(a) CAm means Central America including southern Mexico; SAm means South America; Pan means throughout; Latin Am } \\
\hline \multicolumn{10}{|c|}{\begin{tabular}{|l|l|l|l|l} 
means Central and South America; SE means southeastern; $\mathrm{N}$ means northern. See Table 1. & & & & \\
\end{tabular}} \\
\hline \multicolumn{10}{|c|}{ \# Only species classified by clade in Blanco et al. (2007) are included in this sorting. Differences with Table 1 in the number of species within each genus are due to } \\
\hline \multicolumn{10}{|c|}{\begin{tabular}{|l|l|l} 
a number of species being suspected of being within certain genera (Table 1), but not yet proven. & & \\
\end{tabular}} \\
\hline *My count & of species placed by Blanc & et al. $(2007)$ & in these genera. & not their est & ted total nu & & & & \\
\hline
\end{tabular}

represents a floristically and vegetatively diverse group that ranges from large multifloral cane-like species such as C. biolleyi (Schltr.) Schltr., C. bradeorum Schltr., and C. inauditum (Rchb.f.) M.A.Blanco to the striped miniatures $C$. wercklei Schltr. and $C$. tigrinum (C.Schweinf.) M.A.Blanco to the challenging $C$. cucullatum (Lindl.) M.A.Blanco complex. About 72\% of Camaridium species are endemic to Costa Rica and Panama (Table 3), and only three are exclusively shared with South America and three with the rest of Central America. Only three Camaridium species are reported to be endemic to other Central American countries, and another three have a Pan Latin American distribution. It is therefore a reasonable inference that this genus evolved in the Costa Rica/Panama region.

Since species in this genus largely occur in highland cloud-forest environments, most of these speciation events could not have predated the mountains in which they are endemic, that is, late Cenozoic time (mostly Pliocene and Quaternary or the last 5 million years to 500,000 years depending on the mountain range). Only limited dispersal of this genus to other Latin American countries has evidently occurred since then.
Except for two genera with a small number of species (Inti and Trigonidium), Central American endemic species in other genera in core Maxillariinae, as defined by Whitten et al. (2007) and listed in Blanco et al. (2007), represent minority populations compared to species in those genera in South America (Table 3). Notable among these genera are Maxillaria sensu stricto (only 18\% occur in Central America out of a total of 165 species placed in that genus by Blanco et al. (2007), the largest clade in the subtribe), Maxillariella (32\% of 50 species), Mormolyca (16\% of 25 species), Heterotaxis (31\% of 13 species), Sauvetrea ( $8 \%$ of 13 species), and Ornithidium (17\% of 60 species). Since the geographic centroids of species in these genera are clearly in South America, it is plausible that they originated there. However, this low representation in Central America may be partly a consequence of the smaller land areas of Central American countries compared to South America. The balance of the 17 genera of Whitten et al. (2007) either have few species and/or have few (if any) species in Central America.

The genus Ornithidium has an estimated 60 species, all Neotropical. Among the seven Ornithidium species 
reported in Central America, four are highland species (O. hagsaterianum (Soto Arenas) Senghas, $O$. conduplicatum Ames \& C.Schweinf., O. pittieri Ames, and O. repens (L.O.Williams) M.A.Blanco \& Ojeda), and three are reported to have distribution ranges extending down to lowland forests $(O$. nicaraguense Hamer \& Garay) M.A.Blanco \& Ojeda, $O$. adendrobium (Rchb.f.) M.A.Blanco \& Ojeda, and $O$. fulgens Rchb.f.). Ornithidium fulgens, reported from Bolivia to Mexico and also in Venezuela, is known to be frequently visited and presumably pollinated by hummingbirds (Fogden and Fogden, 2006) and is the most widespread of the genus. A number of species in this clade resemble $O$. fulgens (small, globose or partially closed flowers; bright red, pink or yellow with reflexed sepals and petals; bright yellow, red, or yellow/red, fleshy, and often saccate lips, some reported to produce nectar). These species include: O. aggregatum Rchb.f., O. aureum Poepp. \& Endl., $O$. canarense (J.T.Atwood) M.A.Blanco \& Ojeda, $O$. coccineum (Jacq.) Salisb. ex R.Br. (the type species for the genus Ornithidium), O. conduplicatum Ames \& C.Schweinf., O. giganteum Lindl., O. jamesonii Rchb.f., O. miniatum Lindl., O. pittieri Ames, $O$. ruberrimum (Lindl.) Rchb.f., and $O$. semiscabrum Lindl. All for which we have elevation data occur in highland forests where hummingbirds are said to have a selective advantage over insects in being able to feed at low temperatures (van de Pijl and Dodson, 1966; van der Cingel, 2001). However, O. fulgens is geographically and elevationally widely dispersed, in spite of the presence of many lowland gaps in which hummingbirds do not have such a selective advantage, but to which it is nonetheless evidently well adapted.

\section{Discussion}

The foregoing general observations and interpretations lack specifics regarding precise information on the geographic and elevation distribution of individual species, a limitation that accompanies the exclusive use of country distribution data in this study. More distribution information is now becoming increasingly available online, and collection locations are established using GPS receivers. These advances will enable the use of Geographic Information Systems (GIS) to plot distributions on map bases using advanced satellite-based topographic data, such as the SRTM data (Shuttle Radar Topographic Mission). A recent GIS study by Lorena Endara of orchid distribution in Ecuador shows the power of such methods (Endara et al., 2009). Such methods may also enable the investigator to cross-check geographic data with elevation data and use cultural location information (e.g., state and nearby town and river names) often recorded in older reports. Also, climate and forest cover information may also be compared with orchid species distribution data. Some botanical institutions are already employing these methods.

Another limitation of virtually all sampling is that collections are often conducted in the campaign mode, i.e., go out and collect for a few days or weeks and then return to study your plants and flowers. These collections are valuable but potentially suffer from undersampling because of possibly collecting outside the flowering periods of some species and the small number of forest trees or terrestrial environments actually sampled. The writer is co-founder of the Bosque de Paz Orchid Survey, a 2000-hectare biological reserve located in the upper Río Toro Valley in Alajuela Province in Costa Rica and now in its 7th year. Orchid collections from downed trees and tree limbs are made during maintenance of such as this. Such studies, however, are fairly costly, timeconsuming, and rare.

Finally, the density of sampling for molecular phytogenetics has generally not progressed down to individual species circumscriptions (or closely related species) such that vegetative and floral traits are useful in establishing clues as to dispersion pathways or geographic separations. As orchid genotyping becomes less expensive, and more and more individual plants per species are sequenced, subtle differences in genetic markers may give more clues to these pathways than species distributions alone.

\section{Conclusions}

In a noteworthy recent biography of Charles Darwin, Quammen (2007), author of the immensely popular and readable book about island animal biogeography, the Song of the Dodo, makes an important observation that just as Copernicus (1473-1543) put the sun, rather than planet Earth, at the center of our solar system, Darwin identified a process that placed Homo sapiens as just a mammalian species in a long succession of 
life forms shaped by natural selection. One can take this concept another step. As a geologist in an era of great strides in increasing understanding of our planet Earth, Darwin also helped put our time, our geography, and our climate into a chronology of a long succession of environmental changes that were shaped in part by geological processes. He therefore not only helped enlarge our view of the true time span of life on Earth that enables natural selection to work, but his geological investigations also helped point to how such changes can be drivers for evolution.

Acknowledgments. I thank Melania Mu.oz, BS, MSc, University of Costa Rica, Botanist-in-Charge of the Orchid Project at Bosque de Paz Biological Reserve (www. bosquedepaz.com), Alajuela Province, Costa Rica, for her technical advice and collaboration, and the Gonz.lez family (Federico, Vanessa, and Federico, Jr., owners of the Reserve) for their encouragement and enthusiasm for nature that they show to all their visitors and volunteers. I am especially indebted to Carlos Ossenbach for his encouragement and access to the orchid species database for the Central American Isthmus before publication, and to his colleagues at Lankester Gardens of the University of Costa Rica - Franco Pupulin, Robert Dressler, and Diego Bogar.n - for their encouragement and patience in answering my na.ve and pesky questions. Mark Whitten has been helpful in directing me to core Maxillariinae data and reviewing this paper. Mario Blanco sorted out a number of taxonomic questions among these species. Reviews by marine geologist David Scholl and volcanologist Robert Tilling of the U.S. Geological Survey were valuable and led to marked improvements of this paper. Suggestions by an anonymous reviewer were also especially valuable. I also thank Alec Pridgeon for the opportunity to speak at the 3rd Scientific Conference on Andean Orchids in Quito in February 2009 and contribute to this volume.

\section{LiTERATURE CITED}

Alrich, P. \& W. Higgins. 2008. The Marie Selby Botanical Gardens illustrated dictionary of orchid genera. Cornell University Press, Ithaca, New York, USA.

Atwood, J. T. \& D. E. Mora de Retana. 1999. Flora Costaricensis, Family \#39 Orchidaceae: tribe Maxillarieae: subtribes Maxillariinae and Oncidiinae. Fieldiana, Bot., n.s. 40.

Atwood, J. T. 2003. Maxillaria. Pp. 291-332 in: R. L. Dressler (ed.). Manual de plantas de Costa Rica. Volume 3. Missouri Botanical Garden Press, St. Louis, Missouri, USA.

Baxter, P. J. 2000. Impacts of eruptions on human health. Pp.
1035-1043 in: H. Sigurdsson (ed.). The encyclopedia of volcanoes. Academic Press, New York, USA.

Blanco, M. A., G. Carnevali, W. M. Whitten, R. B. Singer, S. Koehler, N. H. Williams, I. Ojeda, K. M. Neubig \& L. Endara. 2007. Generic realignments in Maxillariinae (Orchidceae). Lankesteriana 7: 515-537.

Burger, W. A. 1985. Why are there so many kinds of flowering plants in Costa Rica? Pp. 125-136 in: W. G. D'Arcy \& M. D. A. Correa (eds.) The botany and natural history of Panama. Missouri Botanical Garden Press, St. Louis, Missouri, USA.

Coates, A. G. 1997. The forging of Central America. Pp. 1-37 in:. A. G. Coates (ed.). Central America: a natural and cultural history Yale University Press, New Haven, Connecticut, USA.

Coats, R. R. 1962. Magma type and crustal structure in the Aleutian arc. In The Crust of the Pacific Basin. Amer. Geophys. Un. Monogr. 6: 92-109.

Costa Rica National Herbarium: http://www.museocostarica. go.cr/herbario

Darwin, C. 1838. On the connexion of certain volcanic phaenomena, and on the formation of mountain-chains and volcanoes, as the effects of continental elevations. Proc. Geol. Soc. London 2: 654-660.

Darwin, C. 1839. Journal of researches into the geology and natural history of the various countries visited by H.M.S. 'Beagle'. 1st edition. Henry Colburn, London, UK.

Darwin, C. 1842. The structure and distribution of coral reefs. Smith, Elder \& Co, London, UK.

Darwin, C. 1844. Geological observations on the volcanic islands visited during the voyage of H.M.S. 'Beagle'. Smith, Elder \& Co, London, UK.

Darwin, C. 1846. Geological observations on South America. Smith, Elder, and Co., London, UK.

Darwin, C. 1858. On the tendency of species to form varieties, and on the perpetuation of varieties by natural means of selection. Proc. Linn. Soc. London (Zool.) 3: $1-52$.

Darwin, C. 1859. On the origin of species by means of natural selection, or the preservation of favoured races in the struggle for life. 1st edition. John Murray, London, UK.

Darwin, C. 1862. On the various contrivances by which British and foreign orchids are fertilized by insects. 1st edition. John Murray, London, UK.

Denyer, P. \& G. E. Alvarado. 2007. Mapa geológico de Costa Rica 2007. Librería Francesca S.A.

Denyer, P., W. Montero \& HG. E. Alvarado. 2003. Atlas tectónico de Costa Rica. Universidad de Costa Rica, San José, Costa Rica.

Dewey, J. F. \& J. M. Bird. 1970. Mountain belts and the new global tectonics. J. Geophys. Res. 75: 2625-2647. 
Dienerstein, E. 2001. A conservation assessment of the terrestrial ecoregions of Latin America and the Caribbean. World Wildlife Fund, Island Press.

Dodson, C. H. 1996. Orchid checklist for Colombia. In Orchids and ecology in Colombia (ed. M. H. Ospina). Santaf. de Bogota, Colombia.

Dodson, C. H. 2002. Native Ecuadorian orchids. Vol. 3. Dodson Trust, Sarasota, Florida, USA.

Dodson, C. H. 2003a. Why are there so many orchid species? Lankesteriana 7: 99-103.

Dodson, C. H. 2003b. Unpublished database of orchid herbarium specimens collected from Ecuador. Courtesy of Mark Whitten, Florida Museum of Natural History, accessed February 2009.

Dodson, C. H. \& R. J. Gillespie. 1967. The biology of the orchids. The Mid-America Orchid Congress, Inc.

Dressler, R. L. 1985. The orchid flora of Panama. Pp. 25-28 in: W. G. D'Arcy \& M. D. A. Correa (eds.). The botany and natural history of Panama. Missouri Botanical Garden Press, St. Louis, Missouri, USA.

Dunsterville, G. C. K. \& L. A. Garay. 1979. Orchids of Venezuela - an illustrated field guide. Botanical Museum of Harvard University, Cambridge, Massachusetts, USA.

Endara, L., N. H. Williams \& S. León-Yánez. 2009. Patterns of endemism of orchids in Ecuador: conservation perspectives and priorities. Pp. 63-70 in: A. M. Pridgeon and J. P. Suárez (eds.), Proceedings of the Second Scientific Conference on Andean Orchids. Universidad Técnica Particular de Loja, Loja, Ecuador.

Fisher, O. 1881. Physics of the Earth's crust. 1st edition. Macmillan, London, UK.

Fogden, M. \& P. Fogden. 2006. Hummingbirds of Costa Rica. Firefly Books, Richmond Hill, Ontario, Canada.

Funk, J., P. Mann, K. D. McIntosh, K. D. \& J. Stephens. 2009. Cenozoic tectonics of the Nicaraguan depression, Nicaragua, and Median trough, El Salvador, based on seismic reflection profiling and remote sensing data. Geol. Soc. Amer. Bull. 121: 1491-1521.

Hágsater, E., M. Á. Soto Arenas, G. A. Salazar Chávez, R. M. Jiménez, M. A. López Rosas \& R. L. Dressler. 2005. Orchids of Mexico. Productos Farmacéuticos, S.A. de C. V., Mexico City, Mexico.

Hall, C. \& H. P. Brignoli. 2003. Historical atlas of Central America. University of Oklahoma Press, Norman, Oklahoma, USA.

Harmon, R. S. 2005. Geological development of Panama. Pp. 45-62 in: R. S. Harmon (ed.). The Rio Chagres, Panama. Springer Verlag, New York, USA.

Haug, G. H., Tiedermann, R., Zahn, R., and Ravelo, A. C. 2001. Role of Panama uplift on oceanic freshwater balance. Geology 29: 207-210.

Herbert, S. 2005. Charles Darwin, geologist. Cornell
University Press, Ithaca, New York, USA.

Holdridge, L. R. 1947. Determination of world plant formations from simple climatic data. Science 105: 367-368.

Holdridge, L. R. 1967. Life zone ecology. Revised edition. Tropical Science Center, San José, Costa Rica.

INBio Database: http:/www.inbio.ac.cr/bims/k03/p13/ c046/o0168/f01336.htm/ accessed 25 January to 8 March, 2009.

Isacks, B., Oliver, J. and Sykes, L. R. 1968. Seismology and the new global tectonics. J. Geophys. Res. 73: 58555899.

Janzen, D. H. 1967. Why mountain passes are higher in the tropics? Amer. Natur. 101: 233-246.

Lankester Botanical Garden Online Database: http://www. epidendra.org/ accessed January 5 to 8 March.

Lyell, C. 1830, 1832, 1833. Principles of geology, being an attempt to explain the former changes of the Earth's surface, by reference to causes now in operation. 1st edition. Volumes 1-3. John Murray, London, UK.

Mahoney, J. J. \& M. R. Coffin (ed.). 1997. Large igneous provinces: continental, oceanic, and planetary flood volcanism. Geophysical Monograph 100, American Geophysical Union, Washington, D.C., USA.

Mallet, R. \& J. W. Mallet. 1858. In The earthquake catalogue of the British Association: with the discussion, curves, and maps, etc., map insert. Reports of the British Association, 3rd and 4th Report, 28th Report of the Association.

Mann, P. (ed.) 1995. Geologic and tectonic development of the Caribbean plate boundary in Central and South America. Geological Society of America Special Paper 295.

Mann, P. \& J. Corrigan, J. 1990. Model for late Neogene deformation in Panama. Geology 18: 558-562.

Mann, P., R. D. Rogers \& L. Gahagan. 2006. Overview of plate tectonic history and its unresolved tectonic problems. Pp. 201-238 in: J. Bundschuh \& G. E. Alvarado (eds.). Central America: geology, resources and hazards Engineering, Water, and Earth Sciences Series, vol. 1. Taylor and Francis, London, UK.

Mason, B. G., D. M. Pyle \& C. Oppenheimer. 2004. The size and frequency of the largest explosive eruptions on Earth. Bull. Volcan. 66: 735-748.

McLeish, I., N. R. Pearce \& B. R. Adams. 1995. Native orchids of Belize. A.A. Balkema, Rotterdam, The Netherlands.

Milne, J. 1886. Earthquakes and other Earth movements. International Scientific Series. D. Appleton, New York, USA.

Misas Urreta, G. 2005. Orquídeas de la Serrania del Baudo Choco Colombia. Corporación Capatalina de Orchideología, Bogotá, Colombia. 
Myers, N., R. A. Mittermeier, C. G. Mittermeier, G. A. B. da Fonseca \& J. Kent. 2000. Biodiversity hotspots for conservation priorities. Nature 403: 853-858.

Nir, M. A. 2000. Orchidaceae Antillanae. DAG Media, New York, USA.

Oliver, J. \& B. Isacks, B. 1967. Deep earthquake zones, anomalous structures in the upper mantle and the lithosphere. J. Geophys. Res. 72: 4259-4275.

Ossenbach, C. 2009. Orchids and orchidology in Central America: 500 years of history. Lankesteriana 9: 1-268.

Ossenbach, C., F. Pupulin \& R. L. Dressler. 2007. Orquídeas del istmo Centroamericano: catalogo y estado de conservación (Orchids of the Central American isthmus: checklist and conservation). Editorial 25 de Mayo, Sabanilla, Costa Rica.

Phipps Morgan, J., C. Ranero \& P. Vannucci. 2008. Intraarc extension in Central America: links between plate motions, tectonics, volcanism, and geochemistry. Earth Planet. Sc. Lett. 272: 365-371.

Quammen, D. 2007. The reluctant Mr. Darwin: an intimate portrait of Charles Darwin and the making of his theory of evolution. W.W. Norton and Co., New York, USA.

Rogers, R. D., P. Mann \& P. A. Emmet. 2007. Tectonic terranes of the Chortis block based on integration of regional aeromagnetic and geologic data. Pp. 65-88 in: P. Mann (ed.), Geologic and tectonic development of the Caribbean plate in northern Central America. Geological Society of America Special Paper 428.

Sak, P. B., D. M. Fisher, T. W. Gardner, J. S. Marshall\& P. C. LaFemina. 2009. Rough crust subduction, forearc kinematics, and Quaternary uplift rates, Costa Rica segment of the Middle American Trench. Geol. Soc. Amer. Bull. 121: 992-1012.

Simkin, T. \& R. S. Fisk. 1985. Krakatoa 1883 - the volcanic eruption and its effects. Smithsonian Institution Press, Washington, D.C., USA.

Simkin, T., R. Tilling, P. Vogt, S. H. Kirby, P. Kimberly \& D. B. Stewart. 2006. This dynamic planet - world map of volcanoes, earthquakes, impact craters, and plate tectonics, U. S. Geological Survey Geologic Investigations Map I-2800, Washington, D.C., USA. Map and Poster. Online interactive version: http:// mineralsciences.si.edu/tdpmap/.

Soto Arenas, M. Á., E. Hágsater, R. M. Jiménez, G. A. Salazar Chávez, R. G. Solano, R. G. Flores \& I. C. Ruiz. 2007. Orchids of Mexico: Digital Catalogue. CDROM. Win-Mac. Herbario AMO, Instituto Chinoin, A.C. Mexico City, Mexico.
Suess, E. 1883-1909. Das Antlitz der Erde. 4 volumes. F. Tempsky, Prague, Czechoslovakia.

Tropicos (Missouri Botanical Garden Online Database): http://www.tropicos.org/ accessed 25 January to 8 March, 2009.

Trusty, J. L. \& M. A. Blanco. 2005. Las orquídeas de la Isla del Coco. Epidendrum 27: 15-18.

Trusty, J. L., H. C. Kesler \& G. H. Delgado. 2006. Vascular flora of Isla del Coco, Costa Rica. Proc. Calif. Ac. Sc., Fourth Ser., 57: 247-355.

van der Cingel, N. A. 2001. An atlas of orchid pollination: America, Africa, Asia, and Australia. A.A. Balkema, Rotterdam, The Netherlands.

van der Pijl, L. \& C. H. Dodson, C. H. 1966. Orchid flowers: their pollination and evolution. University of Miami Press, Coral Gables, Florida, USA.

Wallace, A. R. 1858. On the tendency of varieties to depart indefinitely from the original type. Proc. Linn. Soc. London (Zool.) 3: 53-62.

Wallace, A. R. 1870. Contributions to the theory of natural selection - a series of essays. 1st edition. Macmillan and Co., London, UK.

Wallace, A. R. 1889. Darwinism: an exposition of the theory of natural selection, with some of its applications. 1st edition. Macmillan and Co., London, UK.

Wallace, D. R. 1997. Central American landscapes. Pp. 7296 in: A. G. Coates (ed.). Central America: a natural and cultural history. Yale University Press, New Haven, Connecticut, USA.

Webb, S. D. 1997. The great faunal exchange. Pp. 97-122 in: A. G. Coates (ed.). Central America: a natural and cultural history. Yale University Press, New Haven, Connecticut, USA.

Whitten, W. M., M. A. Blanco, N. H. Williams, S. Koehler, G. Carnevali, R. B. Singer, L. Endara \& K. M. Neubig. 2007. Molecular phylogenetics of Maxillaria and related genera (Orchidaceae: Cymbidieae) based on combined molecular data sets. Amer. J. Bot. 94: 18601889.

World Checklist of Monocotyledons. 2009. The Board of Trustees of the Royal Botanic Gardens, Kew. Published on the Internet; http:/www.kew.org/wcsp/monocots/ accessed 25 January to 8 March, 2009.

Yeats, R. B., K. Sieh \& C. R. Allen. 1997. In The geology of earthquakes. Oxford University Press, Oxford, UK.

Zelenko, H. \& P. Bermúdez. 2009. Orchid species of Peru. ZAI Publications, Quito, Ecuador. 